\title{
Fruits Puree and its Application as Fat Replacers in Biscuits
}

Nareman S. Eshak ${ }^{1}$, and Mohamed Youssef Abdel Hamid Mahmoud ${ }^{2}$

${ }^{1}$ Home Economics Department, Faculty of Specific Education, Assiut University, Egypt

${ }^{2}$ Food Science Depatment, Faculty of Education, Suez Canal University, Egypt

Correspondence: e-mail:

Nariman_Saeed@aun.edu.eg, Fax: 0020882311535
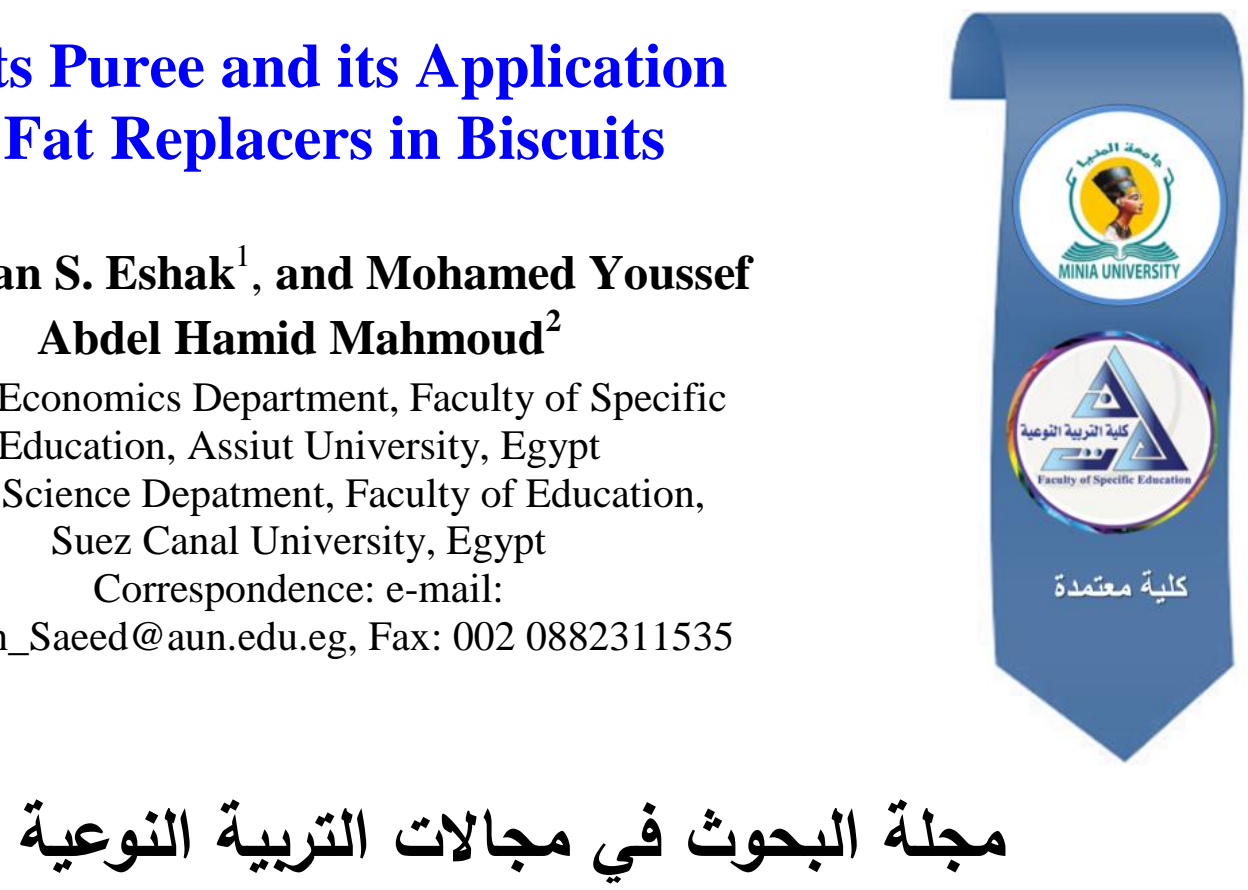

معرف البحث الرقمي DOI: 10.21608/jedu.2021.63900.1265

$$
\text { المجلد السابع العدد } 36 \text { ـ سبتمبر } 2021 \text { الترقيم الدولي }
$$

P-ISSN: 1687-3424

E- ISSN: 2735-3346

https://jedu.journals.ekb.eg/ موقع المجلة عبر بنك المعرفة المصري

http://jrfse.minia.edu.eg/Hom موقع المجلة

العنوان: كلية التربية النوعية ـ جامعة المنيا ـ جمهورية مصر العربية

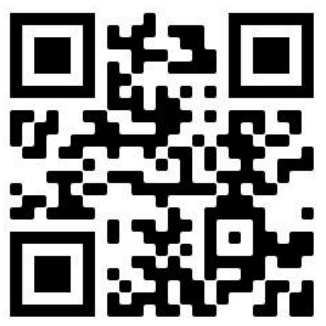


مجلة البحوث فى مجالات التربية النوعية 


\title{
Fruits Puree and its Application as Fat Replacers in Biscuits
}

\author{
Nareman S. Eshak ${ }^{1}$, and Mohamed Youssef Abdel Hamid Mahmoud ${ }^{2}$ \\ ${ }^{1}$ Home Economics Department, Faculty of Specific Education, Assiut University, \\ Egypt \\ ${ }^{2}$ Food Science Depatment, Faculty of Education, Suez Canal University, Egypt \\ Nariman_Saeed@aun.edu.eg
}

\section{Abstract}

This study was carried out to evaluate the effect three types of fruits puree (apple, banana, and cantaloupe) used as fat replacers at three ratios to fat (50:50, 75:25 and 100:0) w/w and high fat biscuit control (100\% fat) to compare in baking biscuits on the chemical composition, physical and functional properties, and sensory evaluation of the biscuits. The results revealed that there was no significant difference between all samples in moisture as compared to the control sample. The highest content of moisture in samples $100 \%$ fat replacement was $2.59 \%$. The fiber, ash and carbohydrate content of the biscuits increased significantly as the replacement level increased. In contrast, the replacement resulted in a sharp significant decrease in fat content. The results increased significantly at $(\mathrm{p} \leq 0.05)$ among samples in weight and thickness of biscuits but the width, volume and specific volume decreased. The highest value of weight and thickness was in samples of $100 \%$ fat replacement $(20.0 \%, 20.01 \%$ and $16.33 \%$ ) in formulas $(2,3,4)$ respectively, and the lowest was found in $50 \%$ fat replacement $(16.0 \%, 13.67 \%$ and $12.52 \%)$. PH of all samples was not significantly different as compared to the control sample. The water absorption capacity of samples $100 \%$ fat replacers had higher than the $50 \%$ fat replacers. The appearance, flavor, taste, texture and overall acceptance, of all biscuits replaced with fruits puree exhibited no significant difference as compared to their control and was highly acceptable except appearance and texture in $100 \%$ fat replacers of apple were significant differences at $(\mathrm{p} \leq 0.05)$.

Key Words: Fruits puree, Fat replacers, Physio-chemical and functional properties. 


\section{Introduction}

Fat has an important role in both taste and texture of baked products (Pooja et al., 2018). Many snack foods rely on dietary fat to fulfill these palatable qualities in order to maintain consumer acceptance and consumption (Kathryn et al., 2018). Several studies have documented that excessive consumption of foods high in fat leads to health problems including obesity (WHO, 2007) which is associated with increased risk of cardiovascular disease (Whitlock et al., 2000), type 2 diabetes mellitus (Abdullah et al., 2010), and some cancers (Renehan et al., 2008). The health-conscious public, demands high quality and lowcalorie products those are low in fat and sugar. However, altering amounts of ingredients to reduce caloric content may compromise texture, mouth feel, flavor and appearance (Jongbin et al., 2010).

Nowadays, consumers are more aware of the adverse effects caused by high fat consumption and consequently, people have approached a diet based on low fat content (Akin and Kirmaci, 2015). Also, consumers are turning their attention increasingly more on functional foods. These products, due to the bioactive functional compounds provide benefits on human health, besides the basic nutritional role (Coelho and Salas-Mellado, 2014). To decrease the increasing weight and improve overall health, many researchers have focused on reducing the fat content in food products by replacing the fat with fruits or vegetables based ingredients (Hayek and Ibrahim, 2013). Replacing dietary fat with fruits and vegetables based ingredients will not only reduce the fat intake, but also provide with nutritional benefits to the product and contribute to increase the consumptions of fruits and vegetables (Pieterse, 2003).

Fat or oil in recipes can be replaced with other food ingredients which include vegetables or fruits purees. These ingredients partially combine with flour to form the structure. In the field of sweet bakery products, studies have been carried out to replace part of the fat with fibers, like; peach fiber, corn bran fiber (Jung et al., 2005), potato pulp and pea flour (Kaack and Pedersen, 2005). Dietary fiber is naturally present in fruits, 
vegetables, cereals, and nuts. A fiber-rich diet is lower in energy density, often has a lower fat content, is larger in volume and is richer in micronutrients (Sanaa, 2015).

Fat replacers were classified into two groups. In the first group are fat mimetics belonging to carbohydrates, proteins, fats or a combination of these three. Carbohydrate-based fat replacers are plant polysaccharides (Chugh et al., 2015). Fruit based fat replacer is also a type of the carbohydrate-based fat replacers. Starch, pectin and cellulose individually and some types of fruit have the ability for being a good fat replacer. Carbohydrate-based fat replacers increased the moisture content of fat reduced product (Kalinga, 2010). The second group includes fat extenders whose task is to optimize the functional properties of fat (Gomez, 2008).

A fat replacer is an ingredient that can be used to provide some or all of the functions of fat yielding fewer calories than fat. It is worth to mention that the term of fat replacer implies that a substance has certain desirable physical or organoleptic attributes of fats which it replaces without any of the undesirable properties of fats (Omayma and Youssef 2007). These fat replacers can provide up to $4 \mathrm{kcal} / \mathrm{g}$, but, because they are often mixed with water, they typically provide only 1 to $2 \mathrm{kcal} / \mathrm{g}$, and, some (such as cellulose) provide zero calories (ADA Reports, 2005).

As baked goods are known to have high percentage of fat, replacement of it with fruits or vegetables contribute to healthier alternatives (Pooja et al., 2018).

Biscuits have been one of the oldest baked goods and consumed extensively all over the world by all age groups. The biscuits formulation can be modified easily to meet the nutritional demands of the target consumers (Chandra et al., 2015). Also, biscuits are dried to low moisture content, and this can ensure their long shelf life storage, and especially free from microbial spoilage (Nguyen and Nguyen, 2018). Mechanical properties of biscuits are largely dependent on the fat component of the formulation. Fat interacts with other ingredients to lubricate and coat the flour granules to prevent water absorption, and the development of starch and gluten in order to achieve a fine crumb crumbly texture) and soft, tender mouth feel and flavor and shelf 
life which is achieved through delaying water absorption by starch granules (Kathryn et al., 2018).

In some recipes for baked goods, apple sauce can be used as a substitute for fat or eggs to make them low-fat or vegan (Wilton, 2014). Apple sauce is a sauce made of apples. It can be made with peeled or unpeeled apples and may be spiced or sweetened. Apple sauce is inexpensive (Erin, 2019). Banana is called Musa spp., and is among the leading fruit crops in the economic value in the world. It is ranked the fifth in the world trade (Guylene et al., 2008). Cantaloupe (Cucumismelo L.) is an important plant from the Cucurbitaceae family. Cantaloupe is one of the most consumed fruit crops worldwide due to its pleasant flavour and nutritional value. Cantaloupes are a diverse group of fresh dessert fruits that includes the orange flesh cantaloupes, green flesh honeydew, and mixed melons (Hanan, 2016).

The aim of the present study is to investigate the effect three types of fruits puree (apple, banana, and cantaloupe) used as fat replacers at different ratios $(0 \%, 50 \%, 75 \%$ and $100 \%)$ in baking biscuits on the chemical composition, physical, functional properties, and sensory evaluation of the biscuits.

\section{Materials and Methods}

\section{Materials}

Wheat flour (72\%), eggs, baking powder, vanillin, oil, sugar powder, and fresh apples, bananas and cantaloupe were purchased from local markets, Assiut, Egypt.

\section{Methods}

\section{Preparation of fruits puree}

\section{Preparation of apple puree}

Apple puree was prepared according to the method of Kulkarni and Joshi (2013) with some modifications. Apples were be washed, and cut into slices then addition of citric acid solution $0.5 \%(\mathrm{w} / \mathrm{v})$ for $20 \mathrm{~min}$ to prevent oxidation. Apple pieces were steamed for 10 minutes and cooked $\left(98^{\circ} \mathrm{C}, 4 \mathrm{~min}\right)$.

\section{Preparation of banana puree}

Preparation of banana purees as method of Wang et al., (2014) with a little modification in this work. The color-protection 
solution $\mathrm{A}$ was a $0.2 \%$ ascorbic acid $(\mathrm{AA})+0.2 \%$ citric acid (CA) mixture and solution $\mathrm{B}(0.3 \% \mathrm{AA}+0.2 \% \mathrm{CA})$. Peeled bananas were immediately put into color-protection solution A to prevent browning, and then solution B was added. Banana puree put into polyethylene bags until use.

\section{Preparation of cantaloupe puree}

Cantaloupe was sorted and removed defective units. It was washed under running tap water to remove soil and organic matter, then dipped for 1 minute in chlorinated water $(100 \mathrm{ppm}$ $\mathrm{NaClO}$ ), and finally rinsed with tap water. After washing, each one was cut in half, parallel to the longitudinal axis seeds and placental tissues were cantaloupe was cut in big chunks and mixed using the blender (Baier et al., 2018).

\section{Preparations of control and formulas biscuits by different concentrations of fruits puree(apples, bananas and cantaloupe)}

The biscuits were made in the laboratory of Assuit University and were prepared according to the method of Kamaliya and Kamaliya, (2001) with replacement the fat by apple, banana, and cantaloupe puree at different levels 0\%, 50\%, 75\% and 100\% w/w. Oil, eggs, vanillin and sugar powder were creamed in a mixer before the homogenized mixture of dried ingredients were added. Then, wheat flour and baking powder were added to the above cream and mixed for 2 min to get the biscuit dough. The dough was cut into round shapes. The cut dough was transferred to trays and baked at $175^{\circ} \mathrm{C}$ for 12 min. Biscuits was packed in stored in air tight containers at room temperature until use for the required analysis and measurements. Fat replacements and numbers of samples are presented in Table (1). The biscuit's photos at different blends are shown in Fig. (1). 
مجلة البحوث في مجالات التربية النوعية

Table (1): Ingredients used in the preparation of control and fat replacement biscuits $(\mathrm{g})$

\begin{tabular}{|c|c|c|c|c|c|c|c|c|}
\hline \multicolumn{2}{|c|}{ Ingredients (g) } & $\begin{array}{c}\text { Oil } \\
(\mathbf{m l})\end{array}$ & $\begin{array}{c}\begin{array}{c}\text { Fat } \\
\text { replacers }\end{array} \\
\text { S }\end{array}$ & Eggs & Vanillin & $\begin{array}{c}\begin{array}{c}\text { Sugar } \\
\text { (powder) }\end{array} \\
\text { (1) }\end{array}$ & $\begin{array}{l}\text { Wheat } \\
\text { flour } \\
\mathbf{7 2 \%}\end{array}$ & $\begin{array}{l}\text { Baking } \\
\text { powder }\end{array}$ \\
\hline \multicolumn{2}{|c|}{ Formulae (1) control } & 100 & 0 & 60 & 1 & 50 & 100 & 1.5 \\
\hline \multirow{3}{*}{$\begin{array}{l}\text { Formulae } \\
\text { (2) Apple } \\
\text { puree }\end{array}$} & $50 \%$ & 50 & 50 & 60 & 1 & 50 & 100 & 1.5 \\
\hline & $75 \%$ & 25 & 75 & 60 & 1 & 50 & 100 & 1.5 \\
\hline & $100 \%$ & 0 & 100 & 60 & 1 & 50 & 100 & 1.5 \\
\hline \multirow{3}{*}{$\begin{array}{c}\text { Formulae } \\
\text { (3) Banana } \\
\text { puree }\end{array}$} & $50 \%$ & 50 & 50 & 60 & 1 & 50 & 100 & 1.5 \\
\hline & $75 \%$ & 25 & 75 & 60 & 1 & 50 & 100 & 1.5 \\
\hline & $100 \%$ & 0 & 100 & 60 & 1 & 50 & 100 & 1.5 \\
\hline \multirow{3}{*}{$\begin{array}{c}\text { Formulae } \\
(4) \\
\text { Cantaloupe } \\
\text { Puree } \\
\end{array}$} & $50 \%$ & 50 & 50 & 60 & 1 & 50 & 100 & 1.5 \\
\hline & $75 \%$ & 25 & 75 & 60 & 1 & 50 & 100 & 1.5 \\
\hline & $100 \%$ & 0 & 100 & 60 & 1 & 50 & 100 & 1.5 \\
\hline
\end{tabular}

The proximate chemical composition of fruits puree and biscuit samples

Moisture, crude protein, crude fiber, crude fat, and ash of the composite biscuits were determined according to the methods of AOAC (2006). Carbohydrates content was calculated by the difference (Latimer, 2012). All estimates were carried out in three times.

$\%$ Carbohydrate $=100-\%($ protein + fat + ash + fiber + moisture $)$ Caloric value of products was calculated according to the following equation:

Total energy value $=($ Protein $\%+$ carbohydrate $\%) \times 4+$ fat $\% \times$ 9 (FAO, 2002)

Where $\mathrm{E}=$ Calories $/ 100 \mathrm{~g}$ product. The results of the experiments were given an average of three replicates. 
مجلة البحوث في مجالات التربية النوعية
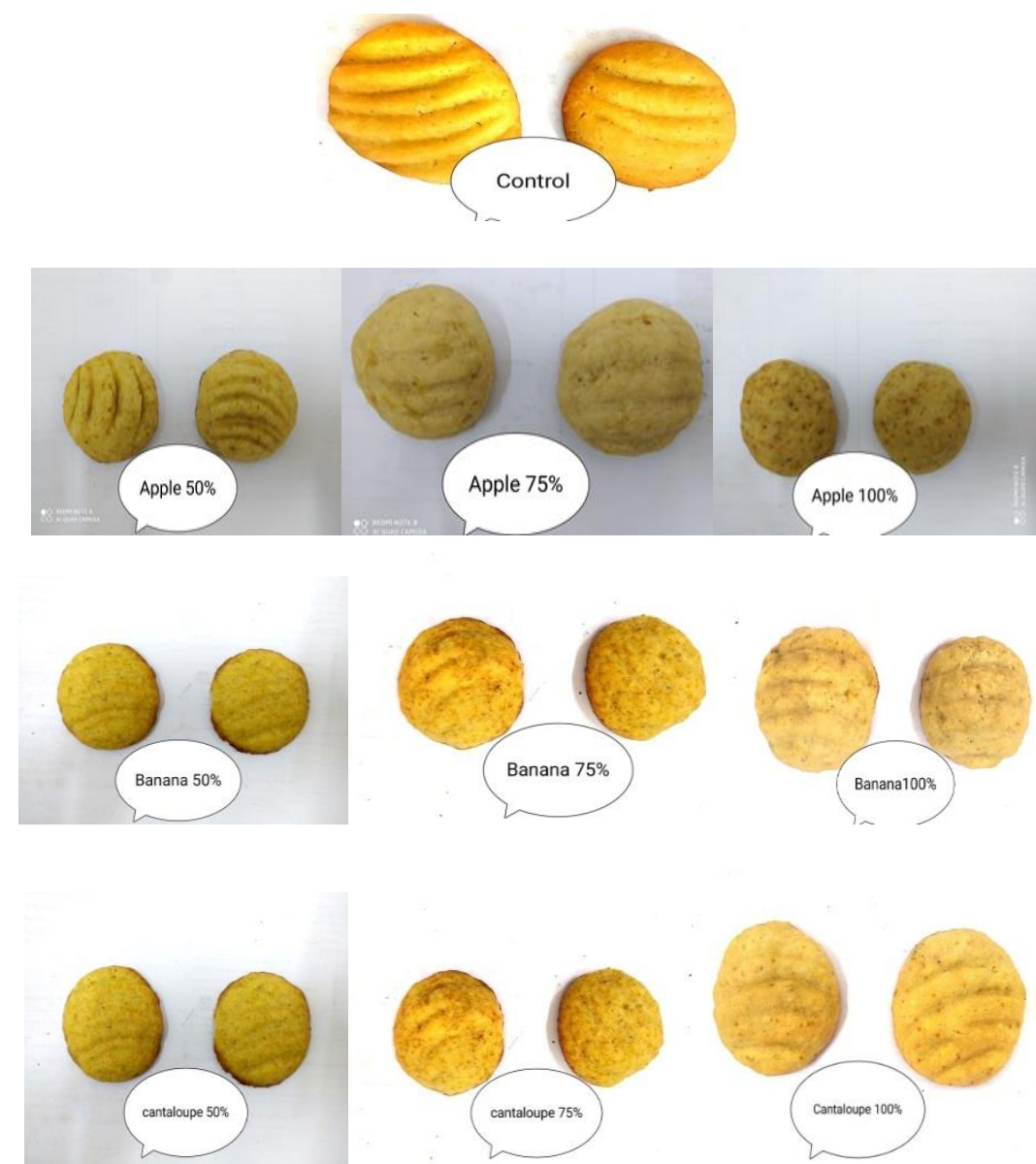

Figure (1): Formulae of control and formulas biscuits with different concentrations of fruits puree $(\mathrm{g} / 100 \mathrm{~g})$

\section{Fat calories}

The percentage of calories related to the calories intake for each sample was calculated as follows:

$\%$ Fat calories $=\frac{\text { Calories of fat }}{\text { Total of calories }} \times 100$

(Sanaa, 2015).

\section{Physical properties of biscuit samples}

The physical properties such as weight, width, thickness, spread ratio, volume, density, specific value and specific gravity were determined. Weight of biscuits was measured as average values of six biscuits with the help of digital weighing scale. The average weight value was reported in grams. Width of biscuits was measured by placing six biscuit samples edge to edge and measuring with a digital vernier caliper. Three values were averaged for each set of samples. The average diameter was 
reported in millimeter. Thickness of biscuits was measured by stacking 6 biscuits on top of each other to get the average value and recorded in millimeters (Jothi et al., 2014). Three values were averaged for each set of samples. Spread ratio was calculated by dividing diameter by thickness (Aida et al., 2017). Volume (ml) was measured by seed displacement (AACC., 2010). Specific volume was calculated as: volume $\left(\mathrm{cm}^{3}\right) /$ weight ( $\mathrm{g}$ ) (Pooja et al., 2018). The $\mathrm{pH}$ of biscuits was measured according to the method of AOAC (2000) using Micro Processor pH Meter (HANNA instruments $\mathrm{pH}$ 2011).

\section{Functional properties of biscuit samples}

Bulk density was determined by following the method described by Onabanjo and Dickson (2014). Ten $\mathrm{ml}$ graduated cylinder, previously tarred, was gently filled with $5 \mathrm{~g}$ of sample. The bottom of the cylinder was gently tapped on a laboratory bench several times until there was to a constant. The bulk density of the sample $(\mathrm{g} / \mathrm{ml})$ was calculated as weight of the sample per unit volume of sample. Water Absorption Capacity (WAC) of the sample was determined using the method as described by Onabanjo and Dickson (2014). A measured quantity (1g) of the sample was dispersed in $10 \mathrm{ml}$ of distilled water in a conical graduated centrifuge tube. The sample was thoroughly mixed for 30 seconds and allowed to stand at room temperature for 30 minutes before being centrifuged at $4000 \mathrm{rpm}$ for another 20 minutes. The volume of the supernatant was measured directly from the graduated centrifuge tube. The amount of the absorbed water was multiplied by the density of water $(1 \mathrm{~g} / \mathrm{ml})$ and results were expressed as g/100 g. Oil Absorption Capacity (OAC) of the flour was determined using the method as described by. One gram of sample was mixed with $10 \mathrm{ml}$ of pure canola oil for 60 seconds. The mixture was set to stand for 10 minutes at room temperature, centrifuged at 4000rpm for 30 minutes and the oil that separated was carefully decanted. The tubes were allowed to drain at an angle of $45^{\circ} \mathrm{C}$ for 10 minutes and then weighed. Oil absorption was expressed as percentage increase of the sample weight (Eleazu and Ironua, 2013).

\section{Sensory evaluation of biscuit samples}




\section{مجلة البحوث فى مجالات التربية النوعية}

Sensory evaluation of biscuits such as appearance, taste, flavor, color, texture, aroma and overall acceptability were assessed by twenty panelists members from academic staff and undergraduate students of the Home Economics Department, Faculty of Specific Education, Assuit university using 9-point hedonic scale (from like extremely $=9$ to dislike extremely $=1$ ) according to Meilgaard et al., (2007).

\section{Statistical analysis}

Data were analyzed using analysis of variance (ANOVA). Means comparison was performed using Duncan's test at the 5\% level of probability as reported by Snedecor and Cochran (1994).

\section{Results and Discussions}

Table (2): Gross chemical composition of fat replacers puree (\% on W.W basis)*

\begin{tabular}{|c|c|c|c|c|c|c|c|c|}
\hline $\begin{array}{c}\text { Fat } \\
\text { replacers } \\
\text { puree }\end{array}$ & $\begin{array}{c}\text { moisture } \\
\%\end{array}$ & $\begin{array}{c}\text { Crude } \\
\text { Protein } \\
\%\end{array}$ & $\begin{array}{c}\text { Crude } \\
\text { Fiber } \\
\%\end{array}$ & $\begin{array}{c}\text { Fat } \\
\%\end{array}$ & $\begin{array}{c}\text { Ash } \\
\%\end{array}$ & $\begin{array}{c}\text { Total } \\
\text { carbohydrate } \\
\%\end{array}$ & $\begin{array}{c}\text { Energy } \\
(\text { kcal/100g) }\end{array}$ & $\begin{array}{c}\text { Fat } \\
\text { calories } \\
(\text { Kcal/1 } \\
00 \mathrm{~g}) \\
\end{array}$ \\
\hline $\begin{array}{c}\text { Fresh } \\
\text { apples }\end{array}$ & $\begin{array}{c}83.2 \pm \\
0.4\end{array}$ & $\begin{array}{c}1.15 \pm \\
0.01\end{array}$ & $\begin{array}{l}2.4 \pm \\
0.01\end{array}$ & $\begin{array}{c}0.31 \\
\pm \\
0.01\end{array}$ & $\begin{array}{c}5.72 \\
\pm \\
0.01\end{array}$ & $\begin{array}{c}7.22 \pm \\
0.01\end{array}$ & $\begin{array}{c}36.27 \pm \\
0.02\end{array}$ & $\begin{array}{c}0.08 \pm \\
0.01\end{array}$ \\
\hline $\begin{array}{c}\text { Fresh } \\
\text { banana }\end{array}$ & $\begin{array}{c}70.8 \pm \\
0.5\end{array}$ & $\begin{array}{l}2.1 \pm \\
0.01\end{array}$ & $\begin{array}{l}2.6 \pm \\
0.02\end{array}$ & $\begin{array}{c}0.81 \\
\pm \\
0.02 \\
\end{array}$ & $\begin{array}{c}14.0 \\
1 \pm \\
0.01 \\
\end{array}$ & $\begin{array}{c}9.68 \pm \\
0.2\end{array}$ & $\begin{array}{c}54.41 \pm \\
0.01\end{array}$ & $\begin{array}{c}0.13 \pm \\
0.01\end{array}$ \\
\hline $\begin{array}{c}\text { Fresh } \\
\text { cantalo } \\
\text { upe }\end{array}$ & $\begin{array}{c}90.2 \pm \\
0.3\end{array}$ & $\begin{array}{c}0.84 \pm \\
0.02\end{array}$ & $\begin{array}{l}0.9 \pm \\
0.01\end{array}$ & $\begin{array}{c}0.19 \\
\pm \\
0.02\end{array}$ & $\begin{array}{c}0.76 \\
\pm \\
0.03\end{array}$ & $\begin{array}{c}7.11 \pm \\
0.04\end{array}$ & $\begin{array}{c}33.51 \pm \\
0.01\end{array}$ & $\begin{array}{c}0.05 \pm \\
0.01\end{array}$ \\
\hline
\end{tabular}

* $(\mathrm{W} . \mathrm{W})$ basis= wet weight basis

The gross chemical composition of fat replacers puree is presented in Table (2). The results indicate that fresh banana was the highest in crude protein, crude fiber, fat, ash, total carbohydrates, total caloric and fat calories. While, it was the lowest in moisture. Fresh cantaloupe was the highest in moisture. These results are in agreement with Chang, (2012) for apples, (Michel et al., 2016) for banana and (Fundo et al., 2018) for cantaloupe.

Table (3) shows the gross chemical composition of control and fat replacement biscuits. There was no significant difference 


\section{مجلة البحوث فى مجالات التربية النوعية}

between all samples in moisture as compared to the control sample. The highest content of moisture in samples $100 \%$ fat replacement was quite reasonable for the reason of having more water in their formulations. Similarity between the moisture content of treatments with just different levels of shortening replacement might be the reduction in fat content (Aida et al., 2017). The moisture content of the control was found to be lower $(2.2 \%)$ than that of the fat replacement biscuits $(2.56 \%)$ in $100 \%$ formulae apple puree and it slowly increased from $50 \%$ to $100 \%$ samples of fat replacement biscuits, because of the higher moisture content in the puree fruits. Similar results on the increase in moisture content were also reported for cookies obtained by replacing butter with avocado puree Roxana et al., 2018). Results are consistent with work by Hanan, (2016) who referred this increase to the high moisture content of cantaloupe purees compared to only moisture of butter.

The addition of puree to biscuits, substituting up to $100 \%$ of fat, produced only a slight increase in protein content, because protein in biscuits mainly came from eggs. Fiber increased, as expected, with the increase in replacement level from $(0.89 \%$ in control$1.45 \%$ in $100 \%$ formulae $\mathbf{3}$, this is due to high fiber content in puree. It is generally agreed that dietary fiber is an available tool in controlling oxidation in food products and as a functional food ingredient (Eleazu and Ironua, 2013). Furthermore, dietary fiber reduces the absorption of cholesterol from the intestine, slows digestion and converts starch into simple sugars, an important factor in controlling diabetes. In addition, fiber components can get better texture, thickening, stabilizing, gelling and emulsifying (Nguyen and Nguyen, 2018).

As expected, the replacement resulted in a sharp significant decrease in fat content, which is in contrast with work by Hussein et al., (2011). On the other hand, this result is agree with Hanan, (2016) who reported that the fat content of biscuits decreased with the reduction of the percentage of fat. 


$$
\text { مجلة البحوث فى مجالات التربية النوعية }
$$

Table (3): Gross chemical composition of control and fat replacement biscuits (\% on W.W basis)

\begin{tabular}{|c|c|c|c|c|c|c|c|c|c|}
\hline \multicolumn{2}{|l|}{ Samples } & $\begin{array}{c}\text { Moisture } \\
\%\end{array}$ & $\begin{array}{c}\text { Crude } \\
\text { Protein \% }\end{array}$ & $\begin{array}{c}\text { Crude } \\
\text { Fiber\% }\end{array}$ & $\begin{array}{c}\text { Fat } \\
\%\end{array}$ & Ash \% & $\begin{array}{c}\text { Total } \\
\text { carbohydrat } \\
\text { e\% }\end{array}$ & $\begin{array}{c}\text { Energy } \\
\text { (kcal/100 } \\
\text { g) } \\
\end{array}$ & $\begin{array}{c}\text { fat calories } \\
\text { (Kcal/ } \\
100 \mathrm{~g}) \\
\end{array}$ \\
\hline \multicolumn{2}{|c|}{$\begin{array}{l}\text { Formulae (1) } \\
\text { control }\end{array}$} & $2.2 \pm 1.0^{\mathrm{a}}$ & $\begin{array}{c}6.56 \pm \\
1.0^{\mathrm{a}}\end{array}$ & $\begin{array}{c}0.89 \pm \\
0.1^{\mathrm{a}}\end{array}$ & $\begin{array}{c}23.7 \\
\pm \\
1.0^{\mathrm{a}}\end{array}$ & $\begin{array}{c}0.5 \pm \\
0.01^{\mathrm{a}}\end{array}$ & $66.15 \pm 3.11^{\mathrm{a}}$ & $\begin{array}{c}504.14 \pm \\
0.56^{\mathrm{a}}\end{array}$ & $\begin{array}{c}42.31 \pm \\
1.74^{\mathrm{a}}\end{array}$ \\
\hline \multirow{3}{*}{$\begin{array}{l}\text { Formula } \\
\text { e (2) } \\
\text { Apple } \\
\text { puree }\end{array}$} & $50 \%$ & $\underset{\mathrm{a}}{2.32 \pm 1.0}$ & $\begin{array}{c}6.67 \pm \\
1.0^{\mathrm{a}}\end{array}$ & $\begin{array}{c}1.15 \pm \\
1.0^{\mathrm{a}}\end{array}$ & $\begin{array}{c}20.0 \\
5 \pm \\
1.0^{\mathrm{b}}\end{array}$ & $\begin{array}{c}5.81 \pm \\
0.1^{\mathrm{b}}\end{array}$ & $69.0 \pm 4.1^{\mathrm{a}}$ & $\begin{array}{c}483.13 \pm \\
3.4^{\mathrm{b}}\end{array}$ & $\begin{array}{c}37.36 \pm \\
2.13^{\mathrm{b}}\end{array}$ \\
\hline & $75 \%$ & $2.45 \pm 1.0$ & $\begin{array}{c}6.69 \pm \\
1.0^{\mathrm{a}}\end{array}$ & $\begin{array}{c}1.26 \pm \\
1.0^{\mathrm{a}}\end{array}$ & $\begin{array}{c}18.4 \\
\pm \\
1.0^{\mathrm{b}}\end{array}$ & $\begin{array}{c}0.85 \pm \\
0.1^{\mathrm{b}}\end{array}$ & $70.35 \pm 4.1^{\mathrm{a}}$ & $\begin{array}{c}473.76 \pm \\
3.4^{\mathrm{b}}\end{array}$ & $\begin{array}{c}34.96 \pm \\
2.15^{\mathrm{b}}\end{array}$ \\
\hline & $\begin{array}{c}100 \\
\%\end{array}$ & $\underset{\mathrm{a}}{2.59 \pm 1.0}$ & $\begin{array}{c}6.72 \pm \\
1.0^{\mathrm{a}}\end{array}$ & $\begin{array}{c}1.35 \pm \\
1.0^{\mathrm{a}}\end{array}$ & $\begin{array}{c}16.0 \\
9 \pm \\
1.0^{\mathrm{b}}\end{array}$ & $\begin{array}{c}0.86 \pm \\
0.1^{\mathrm{b}}\end{array}$ & $72.37 \pm 4.1^{\mathrm{a}}$ & $\begin{array}{c}460.57 \pm \\
2.55^{\mathrm{b}}\end{array}$ & $\begin{array}{c}31.45 \pm \\
2.13^{\mathrm{b}}\end{array}$ \\
\hline \multirow[t]{3}{*}{$\begin{array}{l}\text { Formula } \\
\text { e (3) } \\
\text { Banana } \\
\text { puree } \\
\end{array}$} & $50 \%$ & $\underset{\mathrm{a}}{2.41 \pm 1.0}$ & $\begin{array}{c}6.65 \pm \\
1.0^{\mathrm{a}}\end{array}$ & $\begin{array}{c}1.28 \pm \\
1.0^{\mathrm{a}}\end{array}$ & $\begin{array}{c}20.0 \\
3 \pm 1 \\
0^{\mathrm{b}}\end{array}$ & $\begin{array}{l}0.9 \pm \\
0.1^{b}\end{array}$ & $68.73 \pm 4.1^{\mathrm{a}}$ & $\begin{array}{c}481.7 \pm \\
3.4^{\mathrm{b}}\end{array}$ & $\begin{array}{c}37.45 \pm \\
2.13^{\mathrm{b}}\end{array}$ \\
\hline & $75 \%$ & $\underset{\substack{a \\
2.53 \pm 1.0}}{ }$ & $\begin{array}{c}6.69 \pm \\
1.0^{\mathrm{a}}\end{array}$ & $\begin{array}{c}1.36 \pm \\
1.0^{\mathrm{a}}\end{array}$ & $\begin{array}{c}18.3 \\
6 \pm 1 \\
0^{\mathrm{b}} \\
\end{array}$ & $\begin{array}{c}0.95 \pm \\
0.1^{\mathrm{b}}\end{array}$ & $70.41 \pm 4.14^{\mathrm{a}}$ & $\begin{array}{c}473.81 \pm \\
4.05^{\mathrm{b}}\end{array}$ & $\begin{array}{c}34.93 \pm \\
2.17^{\mathrm{b}}\end{array}$ \\
\hline & $\begin{array}{c}100 \\
\%\end{array}$ & $\underset{\mathrm{a}}{2.65 \pm 1.0}$ & $\begin{array}{l}6.7 \pm \\
1.0^{\mathrm{a}}\end{array}$ & $\begin{array}{c}1.45 \pm \\
1.0^{\mathrm{a}}\end{array}$ & $\begin{array}{c}16.1 \\
\pm \\
1.0^{\mathrm{b}}\end{array}$ & $\begin{array}{c}1.01 \pm \\
1.0^{\mathrm{b}}\end{array}$ & $72.09 \pm 5.0$ & $\begin{array}{c}460.06 \pm \\
5.0^{\mathrm{b}}\end{array}$ & $\begin{array}{c}31.43 \pm \\
2.3^{b}\end{array}$ \\
\hline \multirow{3}{*}{$\begin{array}{c}\text { Formula } \\
\text { e (4) } \\
\text { Cantalo } \\
\text { upe } \\
\text { Puree }\end{array}$} & $50 \%$ & $\underset{\mathrm{a}}{2.29 \pm 1.0}$ & $\begin{array}{c}6.67 \pm \\
1.0^{\mathrm{a}}\end{array}$ & $\begin{array}{c}1.01 \pm \\
1.0^{\mathrm{a}}\end{array}$ & $\begin{array}{c}20.0 \\
4 \pm 1 . \\
0^{\mathrm{b}}\end{array}$ & $\begin{array}{c}0.71 \pm \\
0.1^{\mathrm{b}}\end{array}$ & $69.28 \pm 4.1^{\mathrm{a}}$ & $\begin{array}{c}484.16 \pm \\
3.4^{b}\end{array}$ & $\begin{array}{l}37.27 \pm \\
2.12^{\mathrm{b}}\end{array}$ \\
\hline & $75 \%$ & $\underset{\mathrm{a}}{2.37 \pm 1.0}$ & $\begin{array}{c}6.71 \pm \\
1.0^{\mathrm{a}}\end{array}$ & $\begin{array}{c}1.03 \pm \\
1.0^{\mathrm{a}}\end{array}$ & $\begin{array}{c}18.4 \\
1 \pm 1 \\
0^{\mathrm{b}} \\
\end{array}$ & $\begin{array}{c}0.76 \pm \\
0.1^{\mathrm{b}}\end{array}$ & $70.72 \pm 4.1^{\mathrm{a}}$ & $\begin{array}{c}475.41 \pm \\
3.4^{\mathrm{b}}\end{array}$ & $\begin{array}{c}34.36 \pm \\
2.15^{\mathrm{b}}\end{array}$ \\
\hline & $\begin{array}{c}100 \\
\%\end{array}$ & $\underset{\mathrm{a}}{2.45 \pm 1.0}$ & $\begin{array}{c}6.73 \pm \\
1.0^{\mathrm{a}}\end{array}$ & $\begin{array}{c}4.04 \pm \\
1.0^{\mathrm{a}}\end{array}$ & $\begin{array}{c}16.2 \\
\pm \\
1.0^{\mathrm{b}}\end{array}$ & $\begin{array}{c}0.79 \pm \\
0.1^{\mathrm{b}}\end{array}$ & $72.79 \pm 4.1^{\mathrm{a}}$ & $\begin{array}{c}463.88 \pm \\
3.4^{\mathrm{b}}\end{array}$ & $\begin{array}{c}31.44 \pm \\
2.17^{\mathrm{b}}\end{array}$ \\
\hline
\end{tabular}

* (W.W) basis= wet weight basis

Means with different superscript letters in the same column are significantly different at $\mathrm{P} \leq 0.05$

Results show that the ash content of the biscuits increased significantly as the replacement level increased ranged from ( $0.5 \%$ in control- $5.81 \%$ in $50 \%$ formulae 2 . These results agree with work by Hussein et al., (2011). The ash content of food material could be known as an indication of mineral constituents of the food (Onabanjo and Dickson, 2014). Carbohydrate content was higher in biscuits containing puree $(72.79 \%$ in $100 \%$ formulae 4) than in the control (66.15\%). Also, carbohydrate levels increased with increase in replacement level. This result agrees with Nguyen and Nguyen, (2018). Despite the carbohydrate increase, the caloric value of biscuits decreased, and the differences were statistically significant. 
Concerning the caloric value and fat caloric, a gradual significant decrease was observed as the substitution level in all types of fat replacement at $100 \%$ as compared to the control sample. These results agree with work by Noor et al., (2011). It was reported by Hussein et al., (2011) that the calorie of cakes was significantly $(\mathrm{P} \leq 0.05)$ decreased as the fat replacer levels increased.

Physical properties of control and fat replacement biscuits are presented in Table (4). The weight value and thickness of biscuits was increased gradually with increasing proportion of fat replacers. The highest value was samples of $100 \%$ fat replacement ( $20.0 \%, 20.01 \%$ and $16.33 \%$ ) in formulae $(2,3,4)$ respectively, and the lowest was found in 50\% fat replacement $(16.0 \%, 13.67 \%$ and $12.52 \%)$ in formulae $(2,3,4)$ respectively. The results differed significantly among samples $(\mathrm{p} \leq 0.05)$. As can be seen, the higherlevel fat replacers incorporated the more the weight and thickness of the biscuits. But the width of biscuits was decreased with increasing proportion of fat replacers.

The spread ratio is an important aspect that affected to quality. Jothi et al., (2014) stated that the spread ratio is the important factor that affected to quality parameters of biscuits since it correlated with texture, grain finesse, bite and overall mouth feel of the biscuits. As can be seen, when the level of fat replacers was increased, the spread ratio of biscuits was decreased. Samples of $50 \%$ fat replacers was recorded the highest value of spread ratio, while the lowest value belonged to sample of $100 \%$ fat replacers. In conclusion, the biscuits made from different ratios of fat replacement had lower spread ratio of than that of the control biscuits. These results are partially in agreement with those obtained by Wekwete and Navder, (2008) who reported significantly lower spread ratios were noted in the avocado and Oatrim cookies compared with the control cookies after baking. Pooja et al., (2018) similarly reported fruit puree fat substitutes to restrict dough flow during baking and give a reduced spread. 


$$
\text { مجلة البحوث فى مجالات التربية النوعية }
$$

Table (4): Physical properties of control and fat replacement biscuits

\begin{tabular}{|c|c|c|c|c|c|c|c|c|c|}
\hline \multicolumn{2}{|c|}{ Samples } & $\begin{array}{l}\text { weight } \\
\text { (g) }\end{array}$ & $\begin{array}{l}\text { width } \\
\text { (mm) }\end{array}$ & $\begin{array}{c}\text { thickness } \\
\text { (mm) }\end{array}$ & $\begin{array}{c}\text { spread } \\
\text { ratio }\end{array}$ & $\begin{array}{c}\text { volume } \\
\left(\mathrm{cm}^{3}\right)\end{array}$ & $\begin{array}{l}\text { specific } \\
\text { volume } \\
\left(\mathrm{cm}^{3} / \mathrm{g}\right)\end{array}$ & $\begin{array}{l}\text { Specific } \\
\text { gravity }\end{array}$ & PH \\
\hline \multicolumn{2}{|c|}{$\begin{array}{l}\text { Formulae (1) } \\
\text { control }\end{array}$} & $\begin{array}{c}16.67 \pm \\
1.0^{\mathrm{a}}\end{array}$ & $\begin{array}{c}61.7 \pm \\
1.0^{\mathrm{a}}\end{array}$ & $\begin{array}{c}14.0 \pm \\
1.0^{\mathrm{a}}\end{array}$ & $\begin{array}{l}4.42 \pm \\
0.25^{\mathrm{a}}\end{array}$ & $\begin{array}{c}27.16 \pm \\
1.0^{\mathrm{a}}\end{array}$ & $\begin{array}{l}1.63 \pm \\
0.04^{\mathrm{a}}\end{array}$ & $\begin{array}{l}1.02 \pm \\
0.01^{\mathrm{a}}\end{array}$ & $\begin{array}{l}6.53 \\
\pm 1.0 \\
\mathrm{a}\end{array}$ \\
\hline \multirow[t]{3}{*}{$\begin{array}{c}\text { Formulae } \\
\text { (2) apple } \\
\text { puree }\end{array}$} & $50 \%$ & $\begin{array}{c}16.0 \pm \\
1.0^{\mathrm{a}}\end{array}$ & $\begin{array}{c}53.0 \pm \\
1.0^{\mathrm{b}}\end{array}$ & $\begin{array}{c}16.7 \pm \\
1.0^{\mathrm{a}}\end{array}$ & $\begin{array}{l}3.17 \pm \\
0.13^{\mathrm{b}}\end{array}$ & $\begin{array}{c}20.23 \pm \\
1.0^{\mathrm{b}}\end{array}$ & $\begin{array}{l}1.26 \pm \\
0.02^{\mathrm{b}}\end{array}$ & $\begin{array}{l}0.99 \pm \\
0.01^{\mathrm{b}}\end{array}$ & $\begin{array}{l}6.35 \\
\pm 1.0 \\
\mathrm{a}\end{array}$ \\
\hline & $75 \%$ & $\begin{array}{c}18.3 \pm \\
1.0^{\mathrm{b}}\end{array}$ & $\begin{array}{c}50.1 \pm \\
1.0^{\mathrm{b}}\end{array}$ & $\begin{array}{c}22.1 \pm \\
1.0^{\mathrm{b}}\end{array}$ & $\begin{array}{l}2.28 \pm \\
0.06^{\mathrm{b}}\end{array}$ & $\begin{array}{c}19.21 \pm \\
1.0^{\mathrm{b}}\end{array}$ & $\begin{array}{l}0.96 \pm \\
0.01^{\mathrm{b}}\end{array}$ & $\begin{array}{l}0.97 \pm \\
0.01^{\mathrm{b}}\end{array}$ & $\begin{array}{l}6.34 \\
\pm 1.0 \\
\mathrm{a}\end{array}$ \\
\hline & $\begin{array}{c}100 \\
\%\end{array}$ & $\begin{array}{c}20.0 \pm \\
1.0^{\mathrm{b}}\end{array}$ & $\begin{array}{c}51.0 \pm \\
1.0^{\mathrm{b}}\end{array}$ & $\begin{array}{c}23.0 \pm \\
1.0^{\mathrm{b}}\end{array}$ & $\begin{array}{l}2.22 \pm \\
0.05^{\mathrm{b}}\end{array}$ & $\begin{array}{c}17.98 \pm \\
1.0^{\mathrm{b}}\end{array}$ & $\begin{array}{l}0.98 \pm \\
0.01^{\mathrm{b}}\end{array}$ & $\begin{array}{l}0.94 \pm \\
0.01^{b}\end{array}$ & $\begin{array}{c}6.33 \\
\pm 1.0 \\
\mathrm{a}\end{array}$ \\
\hline \multirow[t]{3}{*}{$\begin{array}{c}\text { Formulae } \\
\text { (3)banana } \\
\text { puree }\end{array}$} & $50 \%$ & $\begin{array}{c}13.67 \pm \\
1.0^{\mathrm{b}}\end{array}$ & $\begin{array}{c}63.3 \pm \\
1.1^{\mathrm{b}}\end{array}$ & $\begin{array}{c}15.0 \pm \\
1.0^{\mathrm{a}}\end{array}$ & $\begin{array}{l}4.23 \pm \\
0.22^{\mathrm{a}}\end{array}$ & $\begin{array}{c}25.43 \pm \\
1.0^{\mathrm{a}}\end{array}$ & $\begin{array}{l}1.88 \pm \\
0.06^{\mathrm{a}}\end{array}$ & $\begin{array}{l}0.93 \pm \\
0.01^{\mathrm{b}}\end{array}$ & $\begin{array}{l}6.39 \\
\pm 1.0 \\
\mathrm{a}\end{array}$ \\
\hline & $75 \%$ & $\begin{array}{c}16.67 \pm \\
1.0^{\mathrm{a}}\end{array}$ & $\begin{array}{c}61.0 \pm \\
1.0^{\mathrm{a}}\end{array}$ & $\begin{array}{c}18.7 \pm \\
1.0^{\mathrm{b}}\end{array}$ & $\begin{array}{l}3.27 \pm \\
0.12^{\mathrm{b}}\end{array}$ & $\begin{array}{c}24.32 \pm \\
1.0^{\mathrm{b}}\end{array}$ & $\begin{array}{l}1.46 \pm \\
0.03^{\mathrm{b}}\end{array}$ & $\begin{array}{l}0.91 \pm \\
0.01^{\mathrm{b}}\end{array}$ & $\begin{array}{l}6.38 \\
\pm 1.0 \\
\mathrm{a}\end{array}$ \\
\hline & $\begin{array}{c}100 \\
\%\end{array}$ & $\begin{array}{c}20.01 \pm \\
1.0^{\mathrm{b}}\end{array}$ & $\begin{array}{c}58.3 \pm \\
1.0^{\mathrm{b}}\end{array}$ & $\begin{array}{c}18.7 \pm \\
1.0^{\mathrm{b}}\end{array}$ & $\begin{array}{l}3.12 \pm \\
0.12^{\mathrm{b}}\end{array}$ & $\begin{array}{c}23.27 \pm \\
1.0^{\mathrm{b}}\end{array}$ & $\begin{array}{l}1.16 \pm \\
0.01^{b}\end{array}$ & $\begin{array}{l}0.87 \pm \\
0.15^{\mathrm{b}}\end{array}$ & $\begin{array}{l}6.37 \\
\pm 1.0 \\
\mathrm{a}\end{array}$ \\
\hline \multirow{3}{*}{$\begin{array}{c}\text { Formulae } \\
(4) \\
\text { cantaloupe } \\
\text { puree }\end{array}$} & $50 \%$ & $\begin{array}{c}12.52 \pm \\
1.0^{\mathrm{b}}\end{array}$ & $\begin{array}{c}66.3 \pm \\
1.0^{\mathrm{b}}\end{array}$ & $\begin{array}{c}14.2 \pm \\
1.0^{\mathrm{a}}\end{array}$ & $\begin{array}{l}4.67 \pm \\
0.39^{\mathrm{a}}\end{array}$ & $\begin{array}{c}15.47 \pm \\
1.0^{\mathrm{b}}\end{array}$ & $\begin{array}{l}1.24 \pm \\
0.02^{\mathrm{b}}\end{array}$ & $\begin{array}{l}0.89 \pm \\
0.01^{b}\end{array}$ & $\begin{array}{c}6.42 \\
\pm 1.0 \\
\mathrm{a}\end{array}$ \\
\hline & $75 \%$ & $\begin{array}{c}14.45 \pm \\
1.0^{\mathrm{b}}\end{array}$ & $\begin{array}{c}64.2 \pm \\
1.0^{\mathrm{b}}\end{array}$ & $\begin{array}{c}14.6 \pm \\
1.0^{\mathrm{a}}\end{array}$ & $\begin{array}{l}4.41 \pm \\
0.23^{\mathrm{b}}\end{array}$ & $\begin{array}{c}14.36 \pm \\
1.0^{\mathrm{b}}\end{array}$ & $\begin{array}{l}0.99 \pm \\
0.01^{\mathrm{b}}\end{array}$ & $\begin{array}{l}0.85 \pm \\
0.01^{\mathrm{b}}\end{array}$ & $\begin{array}{l}6.41 \\
\pm 1.0 \\
\mathrm{a}\end{array}$ \\
\hline & $\begin{array}{c}100 \\
\%\end{array}$ & $\begin{array}{c}16.33 \pm \\
1.0^{\mathrm{a}}\end{array}$ & $\begin{array}{c}63.3 \pm \\
1.0^{\mathrm{b}}\end{array}$ & $\begin{array}{c}16.0 \pm \\
1.0^{\mathrm{b}}\end{array}$ & $\begin{array}{l}3.96 \pm \\
0.19^{\mathrm{b}}\end{array}$ & $\begin{array}{c}13.29 \pm \\
1.0^{\mathrm{b}}\end{array}$ & $\begin{array}{l}0.81 \pm \\
0.01^{\mathrm{b}}\end{array}$ & $\begin{array}{l}0.83 \pm \\
0.01^{\mathrm{b}}\end{array}$ & $\begin{array}{l}6.4 \pm \\
1.0^{\mathrm{a}}\end{array}$ \\
\hline
\end{tabular}

Means with different superscript letters in the same column are significantly different at $\mathrm{P} \leq 0.05$

Volume is a very important quality for biscuits, which strongly influences consumer preference and is directly related to the type and amount of shortening used (Hanan, 2016). In this study, increasing the amount of fat replacer at the different fat reduction level caused to significant decrease in the volume of the products. Replacement of fat in biscuits was also resulted with lower volume products compared with the control samples (27.16\%). These results are in agreement with those obtained (Kocer $\boldsymbol{e t}$ al., 2007 and Zahn et al., 2010). This might be explained by two possible mechanisms. The first one is the increasing amount of fat replacers used in the formulations may lead to the gluten dilution, which affect the optimal gluten matrix formation during the mixing, fermentation and baking steps (Feili et al., 2013). The second possible mechanism is the decrease in the amount of air bubbles, which incorporated into the dough during mixing and expand during baking (Zahn et al., 2010). In another study 
conducted by Seher and Sedat (2017), it was also indicated that the decrease in fat content caused to lower volume in high ratio layer cakes.

Concerning specific volume and specific gravity, there was significant difference $(\mathrm{p} \leq 0.05)$ between specific volume of samples of fat replacers of biscuits and control. The highest value of specific volume and specific gravity in biscuits was of samples $50 \%$ fat replacers $1.26 \& 0.99$ in formulae (2), $1.88 \& 0.93$ in formulae (3), and $1.24 \& 0.89$ in formulae (4) respectively, and the lowest value was of samples $100 \%$ of fat replacers $0.98 \& 0.94$ in formulae (2), $1.16 \& 0.87$ in formulae (3), and $0.81 \& 0.83$ in formulae (4) respectively. Specific volume was recorded as best index of sensory texture of biscuits. These results were in line with the results of previous research of author about reduced-fat cake containing oat bran derivative (Hashemiravan et al., 2013). Lower in specific volume is associated with good aeration of the batter, better crispiness and higher textural value (Dogan, 2006). Specific gravity values of biscuits prepared with fat replacers were significantly lower than that of control biscuits. Similar results were obtained by Hussein et al., (2011) and Capriles et al., (2008) who reported that the specific gravity of the cake batter prepared with more than $50 \%$ fat replacement level was higher than the control.

The $\mathrm{pH}$ of all samples by fat replacements of final products was not significantly different from the control. This result is in agreement with those obtained by Shouk and Sawsan (2005). According to Hanan, (2016), $\mathrm{pH}$ is of great importance in the definition of color and texture of products. Texture tends to become softer as the $\mathrm{pH}$ increases.

For food processing, and food preparation, functional properties of foods are significant properties to establish the applications and uses of food material since they concern the general quality of foods. The important functional properties so as to be usually assayed include: bulk density, water absorption capacity, and oil absorption capacity (Guerin et al., 2011). The results of functional properties control and fat replacement biscuits are as showed in Table (5). 
مجلة البحوث في مجالات التربية النوعية

Table (5): Functional properties of control and fat replacement biscuits

\begin{tabular}{|c|c|c|c|c|}
\hline Samples & & $\begin{array}{c}\text { Bulk Density } \\
(\mathrm{g} / \mathrm{ml})\end{array}$ & $\begin{array}{c}\text { WAC } \\
(\mathrm{g} / \mathrm{g})\end{array}$ & $\begin{array}{l}\text { OAC } \\
(\mathrm{g} / \mathrm{g})\end{array}$ \\
\hline Formulas (1) control & & $0.45 \pm 0.1^{\mathrm{a}}$ & $1.12 \pm 0.25^{\mathrm{a}}$ & $1.8 \pm 0.4^{\mathrm{a}}$ \\
\hline \multirow[t]{3}{*}{ Formulas (2) Apple puree } & $50 \%$ & $0.42 \pm 0.1^{b}$ & $1.05 \pm 0.25^{\mathrm{a}}$ & $1.68 \pm 0.4^{\mathrm{a}}$ \\
\hline & $75 \%$ & $0.44 \pm 0.1^{b}$ & $1.0 \pm 0.25^{\mathrm{b}}$ & $1.6 \pm 0.4^{\mathrm{a}}$ \\
\hline & $100 \%$ & $0.46 \pm 0.22^{b}$ & $0.82 \pm 0.28^{b}$ & $1.32 \pm 0.44^{\mathrm{a}}$ \\
\hline \multirow[t]{3}{*}{ Formulas (3) Banana puree } & $50 \%$ & $0.40 \pm 0.1^{b}$ & $1.0 \pm 0.25^{\mathrm{b}}$ & $1.6 \pm 0.4^{\mathrm{a}}$ \\
\hline & $75 \%$ & $0.42 \pm 0.1^{b}$ & $1.05 \pm 0.25^{\mathrm{b}}$ & $1.68 \pm 0.4^{\mathrm{a}}$ \\
\hline & $100 \%$ & $0.45 \pm 0.1^{\mathrm{b}}$ & $1.12 \pm 0.25^{\mathrm{b}}$ & $1.8 \pm 0.4^{\mathrm{a}}$ \\
\hline \multirow{3}{*}{$\begin{array}{l}\text { Formulas (4) Cantaloupe } \\
\text { puree }\end{array}$} & $50 \%$ & $0.32 \pm 0.1^{b}$ & $0.8 \pm 0.25^{b}$ & $1.28 \pm 0.4^{\mathrm{a}}$ \\
\hline & $75 \%$ & $0.34 \pm 0.1^{b}$ & $0.85 \pm 0.25^{\mathrm{b}}$ & $1.36 \pm 0.4^{\mathrm{a}}$ \\
\hline & $100 \%$ & $0.36 \pm 0.1^{b}$ & $0.9 \pm 0.25^{b}$ & $1.44 \pm 0.4^{\mathrm{a}}$ \\
\hline
\end{tabular}

Means with different superscript letters in the same column are significantly different at $\mathrm{P} \leq 0.05$

Scientifically and economically, bulk density is an important factor, second only to moisture. The bulk density also content generally affected by the particle size and density of the flour and so, it is a really important approach to determining the type of packaging material required, material handling and application in wet processing in the food industry (Adeleke and Adedeji, 2010 \& Onabanjo and Dickson, 2014). Henceforward, when the particle size was increased, bulk density was decreased. Consequently, enhancement in bulk density is really necessary as it takes advantage in package processing, then a greater quantity may be packed within a constant volume (Eleazu and Ironua, 2013).

During dough preparation, it was observed that the fat replaced fruits puree, dough were stickier and more difficult to work when compared to the control dough. Presence of non-cereal protein maybe a reason for sticky dough, due to its higher water holding capacity. Water absorption is a capacity of a product to link with water under conditions where water is limiting such as doughs and pastes (Eleazu and Ironua, 2013). The ability of flour to absorb water is called as water absorption capacity. Eleazu and Ironua, 
(2013) mentioned that high digestibility of the starch is based on increase in WAC. In food system, the feature of WAC is to improve yield, consistency of food (Chandra et al., 2015). From the results above, the water absorption capacity of samples $100 \%$ fat replacers had higher than the $50 \%$ fat replacers, hence, this resulted in the higher initial moisture content of the dough and the higher loss of water during baking of the biscuits (Sneha et al., 2012). This might be responsible for texture particularly hardness, hence hardness and factorability of optimized sample has been increased (Kulkarni and Joshi, 2013). However, the differences of two attributes among samples were insignificant $(\mathrm{p} \leq 0.05)$.

The collected data revealed that the results of the study recorded no significant difference in OAC for all samples compare to control. Among all fat replacers samples, samples 50\% recorded the highest value in $\operatorname{OAC}(1.68,1.6,1.28)$ in formulas $(2,3,4)$ respectively, and the samples $100 \%$ recorded the least value $(1.32$, $1.8,1.44)$ in formulas $(2,3,4)$ respectively. The OAC of samples slightly decreased as more and more fat replacers was incorporated, which indicated diluting effect of fat replacers on OAC. According to the observation of Nguyen and Nguyen (2018), the oil absorption capacity interrelated to the ability of proteins to attach fat is important property in food formulations since fats be active as flavor retainer and improve the mouth feel of foods.

The produced biscuits using fat replacers with different ratios of fruits puree were sensory evaluated and compared with control biscuits with $100 \%$ fat. The results of all attributes (color, appearance, flavor, taste, texture and overall acceptance are given in Table 6. It is clear that samples of biscuits are acceptable. Color is one of the most important parameters that affect directly the consumer preference of any product. Several researchers also found that yellow color of food products increased mean scores of panelists in color attribute (Kia and Hosseini, 2018). 


$$
\text { مجلة البحوث فى مجالات التربية النوعية }
$$

Table (6): Sensory evaluation of control and fat replacement biscuits

\begin{tabular}{|c|c|c|c|c|c|c|c|}
\hline \multicolumn{2}{|c|}{ Samples } & \multirow{2}{*}{$\begin{array}{c}\begin{array}{c}\text { Color } \\
(\mathbf{1 0})\end{array} \\
9.7 \pm \\
1.0^{\mathrm{a}}\end{array}$} & \multirow{2}{*}{$\begin{array}{c}\begin{array}{c}\text { Appearance } \\
\text { (10) }\end{array} \\
9.8 \pm 1.0^{\mathrm{a}}\end{array}$} & \multirow{2}{*}{$\begin{array}{c}\begin{array}{c}\text { Flavor } \\
\text { (10) }\end{array} \\
9.7 \pm 1.0^{\mathrm{a}}\end{array}$} & \multirow{2}{*}{$\begin{array}{c}\begin{array}{c}\text { Taste } \\
(\mathbf{1 0})\end{array} \\
9.8 \pm 1.0^{\mathrm{a}}\end{array}$} & \multirow{2}{*}{$\begin{array}{c}\begin{array}{c}\text { Texture } \\
\text { (10) }\end{array} \\
9.5 \pm 1.0^{\mathrm{a}}\end{array}$} & \multirow{2}{*}{$\begin{array}{c}\begin{array}{c}\text { Overall } \\
\text { acceptability } \\
(\mathbf{1 0})\end{array} \\
9.8 \pm 1.0^{\mathrm{a}}\end{array}$} \\
\hline $\begin{array}{l}\text { Formula } \\
\text { contr }\end{array}$ & & & & & & & \\
\hline \multirow{3}{*}{$\begin{array}{l}\text { Formulas } \\
\text { (2) Apple } \\
\text { puree }\end{array}$} & $50 \%$ & $\begin{array}{l}9.5 \pm \\
1.0^{\mathrm{a}}\end{array}$ & $9.0 \pm 1.0^{\mathrm{a}}$ & $9.3 \pm 1.0^{\mathrm{a}}$ & $9.5 \pm 1.0^{\mathrm{a}}$ & $9.1 \pm 1.0^{\mathrm{a}}$ & $9.6 \pm 1.0^{\mathrm{a}}$ \\
\hline & $75 \%$ & $\begin{array}{l}9.3 \pm \\
1.0^{\mathrm{a}}\end{array}$ & $9.0 \pm 1.0^{\mathrm{a}}$ & $9.3 \pm 1.0^{\mathrm{a}}$ & $9.5 \pm 1.0^{\mathrm{a}}$ & $9.1 \pm 1.0^{\mathrm{a}}$ & $9.6 \pm 1.0^{\mathrm{a}}$ \\
\hline & $\begin{array}{c}100 \\
\%\end{array}$ & $\begin{array}{l}8.5 \pm \\
1.0^{\mathrm{a}}\end{array}$ & $7.6 \pm 1.0^{b}$ & $9.2 \pm 1.0^{\mathrm{a}}$ & $8.9 \pm 1.0^{\mathrm{a}}$ & $7.3 \pm 1.0^{b}$ & $8.9 \pm 1.0^{\mathrm{a}}$ \\
\hline \multirow{3}{*}{$\begin{array}{c}\text { Formulas } \\
\text { (3) } \\
\text { Banana } \\
\text { puree }\end{array}$} & $50 \%$ & $\begin{array}{l}9.2 \pm \\
1.0^{\mathrm{a}}\end{array}$ & $9.3 \pm 1.0^{\mathrm{a}}$ & $9.1 \pm 1.0^{\mathrm{a}}$ & $9.2 \pm 1.0^{\mathrm{a}}$ & $9.0 \pm 1.0^{\mathrm{a}}$ & $9.2 \pm 1.0^{\mathrm{a}}$ \\
\hline & $75 \%$ & $\begin{array}{l}9.2 \pm \\
1.0^{\mathrm{a}}\end{array}$ & $9.2 \pm 1.0^{\mathrm{a}}$ & $9.2 \pm 1.0^{\mathrm{a}}$ & $9.2 \pm 1.0^{\mathrm{a}}$ & $8.2 \pm 1.0^{\mathrm{a}}$ & $9.1 \pm 1.0^{\mathrm{a}}$ \\
\hline & $\begin{array}{c}100 \\
\%\end{array}$ & $\begin{array}{l}8.2 \pm \\
1.0^{\mathrm{a}}\end{array}$ & $8.1 \pm 1.0^{\mathrm{a}}$ & $9.0 \pm 1.0^{\mathrm{a}}$ & $8.9 \pm 1.0^{\mathrm{a}}$ & $8.0 \pm 1.0^{\mathrm{a}}$ & $8.3 \pm 1.0^{\mathrm{a}}$ \\
\hline \multirow{3}{*}{$\begin{array}{c}\text { Formulas } \\
(4) \\
\text { cantalou } \\
\text { pe } \\
\text { puree }\end{array}$} & $50 \%$ & $\begin{array}{l}9.6 \pm \\
1.0^{\mathrm{a}}\end{array}$ & $9.6 \pm 1.0^{\mathrm{a}}$ & $9.6 \pm 1.0^{\mathrm{a}}$ & $9.6 \pm 1.0^{\mathrm{a}}$ & $9.5 \pm 1.0^{\mathrm{a}}$ & $9.5 \pm 1.0^{\mathrm{a}}$ \\
\hline & $75 \%$ & $\begin{array}{l}9.5 \pm \\
1.0^{\mathrm{a}}\end{array}$ & $9.6 \pm 1.0^{\mathrm{a}}$ & $9.5 \pm 1.0^{\mathrm{a}}$ & $9.4 \pm 1.0^{\mathrm{a}}$ & $9.4 \pm 1.0^{\mathrm{a}}$ & $9.5 \pm 1.0^{\mathrm{a}}$ \\
\hline & $\begin{array}{c}100 \\
\%\end{array}$ & $\begin{array}{l}9.5 \pm \\
1.0^{\mathrm{a}}\end{array}$ & $9.6 \pm 1.0^{\mathrm{a}}$ & $9.3 \pm 1.0^{\mathrm{a}}$ & $9.3 \pm 1.0^{\mathrm{a}}$ & $9.4 \pm 1.0^{\mathrm{a}}$ & $9.4 \pm 1.0^{\mathrm{a}}$ \\
\hline
\end{tabular}

Means with different superscript letters in the same column are significantly different at $\mathrm{P} \leq 0.05$

The collected data revealed that there was a slight change in all samples of biscuits produced containing fruits puree as fat replacers at all levels, it was statistically similar. At 50\% amount of fat replacers, all five attributes obtain the highest scores. There were significant differences in appearance and texture $(\mathrm{p} \leq 0.05)$ in $100 \%$ fat replacers of apple (7.6 and 7.3) respectively. The appearance, flavor, taste, texture and overall acceptance, all biscuits replaced with fruits puree exhibited no significant difference as compared to their control and were highly acceptable. The results of the evaluation also showed that biscuits fat replacers of cantaloupe were more accepted than others samples compare with control. These results are outlined with Wekwete and Navder (2008) in their study with avocado puree replacement levels, showed that there was no significant difference $(\mathrm{p} \leq 0.05)$ observed in texture scores of control cookies having of avocado puree. The overall acceptability scores range suggests that all the experimental cookies were accepted by the panelists. 
According to Colla $\boldsymbol{e t}$ al., (2018), a successful fat-replacement product must replicate texture, mouth feel, and flavor of the original fat. It can be concluded that fruits (apple, banana and cantaloupe) puree could be used as a successful fat replacer in baked products especially biscuits, thus allowing production of potentially healthier food items. Thus, it could be quite worthwhile for commercial applications of healthy food. The increase of fat replacement did not increase hardness of biscuits, but improve their textural properties with lower caloric value. These results are in agreement with those obtained by (El-Sayed et al., 2014).

Fruits puree was the most successful fat replacer in biscuits as it was able to retain most sensory properties of a traditional biscuit even at different level of fat replacers, although there was a decrease in hardness (Wekwete and Navder, 2008). However, it should also be noted that fruits puree were able to increase the sensory qualities and consumer acceptance of biscuits (Romanchik-Cerpovicz et al., 2018).

\section{Conclusion}

The present study showed that fruits puree is an acceptable fat replacer in biscuits and effective in reducing the amount of fat and, as a result the calories. In addition to that fat replacement by different ratios of fruits puree to biscuits was not only improved in nutritional value and health benefits, but also highly accepted by various consumers. Also, fruits puree able to maintain the physical-chemical and sensory characteristics.

Based on this finding it is recommended that the future work needs to focus on the role of fat replacers in other baked goods. 


\section{References}

Abdullah, A., Peeters, A., de Courten, M., and Stoelwinder, J. (2010): The magnitude of association between overweight and obesity and the risk of diabetes: A meta-analysis of prospective cohort studies. Diabetes Res. Clin. Pract., 89, 309-319.

ADA Reports (2005): Position of the American Dietetic Association: Fat Replacers. Journal of the American Dietetic Association, 105: 266-275.

Adeleke, R., and Odedeji, J. (2010): Functional properties of wheat and sweet potato flour blends. Pakistan Journal of Nutrition; 9:535-538.

Aida, D., Amir, H., Reza, A. (2017): Effect of pumpkin powder as a fat replacer on rheological properties, specific volume and moisture content of cake. Banat's Journal of Biotechnology; 16: 116.

Akin, M., and Kirmaci, Z. (2015): Influence of fat replacers on the chemical, textural and sensory properties of low-fat Beyaz pickled cheese produced from ewe's milk. International Journal of Dairy Technology, 68: 127-135.

AACC, (2010): Approved Methods of American Association of Cereal Chemists. St. Paul, USA: American Association of Cereal Chemists. $11^{\text {th }}$ Edition.

AOAC, (2000): Association of Official Analytical Chemistry. Official Method of Analysis (AOAC) International, 17th edition. Maryland U.S.A.

AOAC, (2006): Official Methods of Analysis, 18th Ed., Association of Official Analytical Chemists International, Gaithersburg, MD.

Baier, L., Lacey, Meg, Boone, M., Owens, J., Paul, P. and Owens-Peters, S. (2018): How to Make Pumpkin Puree. Retrieved from https://www.asweetpeachef.com/how-to-makepumpkin-puree.

Capriles, V., Almeida, E., Ferreira, R., Areas, J., Steel, C., and Chang, Y., (2008): Physical and sensory properties of regular and reduced-fat pound cakes with added amaranth flour. Cereal chemistry, 85 (5), 614-618. 
Chandra, S. et al., (2015): Evaluation of functional properties of composite flours and sensorial attributes of composite flour biscuits. Journal of food science and technology; 52:3681-3688.

Chang, Y., (2012): Common Nutrients and Nutraceutical Quality of Apples. New York Fruit Quarterly; 20(3), 3-7.

Chugh, B., Singh, G., and Kumbhar, B. (2015): Studies on the Optimization and Stability of Low-Fat Biscuit Using Carbohydrate-Based Fat Replacers. International Journal of Food Properties, 18(7), 1446-1459.

Coelho, M., Salas-Mellado, M. (2014): Chemical characterization of CHIA (Salvia hispanica L.) for use in food products. Journal of Food and Nutrition Research, 2: 263-269.

Colla, K., Costanzo, A., and Gamlath, S. (2018): Fat Replacers in Baked Food Products. Foods, 7(12), 192.

Dogan, I. (2006): Effect of Oven Types on the Characteristics of Biscuits Made from Refrigerated and Frozen Doughs. Food Technology \& Biotechnology; 44(1).

Eleazu, C., and Ironua, C. (2013): Physicochemical composition and antioxidant properties of a sweet potato variety (Ipomoea batatas L) commercially sold in South Eastern Nigeria. African Journal of Biotechnology; 12(7): 720-727.

El-Sayed, M., Shaltout, O., El-Difrawy, E., Osman, H. and Abo-El Naga, M. (2014): Production and Evaluation of Low Fat Cake Containing Flaxseed and Okra gums as a Fat Replacer. Alex. J. Fd. Sci. \& Technol; 11(1), pp. 53-60.

Erin, H. (2019): The 11 Best Apples for Applesauce, The Spruce Eats.

FAO, (2002): Food energy - methods of analysis and conversion factors. Food and Nutrition Paper 77. Report of a technical workshop, Rome, 3-6 December. ISSN 0254-4725: 1-100.

Feili, R., Abdullah, W., and Yang, T. (2013): Physical and sensory analysis of high fiber bread incorporated with jackfruit rind flour. Food Science and Technology, 1(2), 30-36.

Fundo, J., Miller, F., Garcia, E., Santos, J., Silva, C., Brandao, T. (2018): Physicochemical characteristics, bioactive compounds and antioxidant activity in juice, pulp, peel and seeds of Cantaloupe melon. J. Food Meas. Charact; 12:292-300. 
Gomez, M. (2008): Functions of ingredients in the baking of sweet goods. In Food Engineering Aspects of Baking Sweet Goods (S.G. Sumru and S. Sahin, eds.) pp. 245-273, Taylor \& Francis Group, London, U.K.

Guerin, D., Pochat, M., Reife, C., Wils, D., Cho, S., and Miller, L. (2011): The soluble fiber Nutrios induces a dose-dependent beneficial impact on satiety over time in humans. Nutrition research; 31(9):665-672.

Guylene, A., Berthe, P., Louis, F. (2008): Bananas, Raw materials for making processed food products. Trends Food Sci. Technol. 20 (2), 1-3.

Hanan, A. (2016): Using Vegetable Puree as a Fat Substitute in Cakes. International Journal of Nutrition and Food Sciences; 5(4): 284-292.

Hashemiravan, M., Dadkhah, A., Seyedain-Ardebili, M. (2013): Effects of shortening replacement with Nutrim oat bran on $\mathrm{pH}$, specific volume, hardness and sensory properties of shortened cake. Journal of Food Research, 23(1), 97-106.

Hayek, S., and Ibrahim, S. (2013): Consumer acceptability of chocolate chip cookies using applesauce as a fat (butter) substitute. Emirates Journal of Food and Agriculture; 25(3):159. Hussein, E., El-Beltagy, A., and Gaafor, A. (2011): Production and quality evaluation of low calorie cake. American journal of food technology, 6 (9), 827-834. Jissy, J., and Leelavathi, K. (2007): Effect of fat-type on cookie dough and cookie quality. Journal of Food Engineering, 79, 299-305. Jongbin, L., George, E., and Suyong, L. (2010): Response to consumer demand for reduced fat foods; Multi- functional fat replacers. Japan Journal of Food Engineering, 11:147- 152.

Jothi, J. et al., (2014): Effect of Gluten-free Composite Flour on Physico-chemical and Sensory Properties of Cracker Biscuits. Journal of Scientific Research; 6(3):521-530.

Jung, J., Kim, S., and Chung, H. (2005): Quality characteristics of low-fat muffincontaining corn bran fiber. Journal of the Korean Society of Food Science and Nutrition, 34(5), 694e699. 
Kaack, A., and Pedersen, L. (2005): Low energy chocolate cake with potato pulp and yellow pea hulls. European Food Research and Technology, 221, 367e375.

Kalinga, D. (2010): Delivering $\beta$-glucan via selected bakery systems: cake. Master Thesis. Victoria University. Faculty of Health, Engineering and Science: Virginia, USA., 8-85. Kamaliya, M., and Kamaliya, K. ( 2001): Baking Science and Industries. 1st Edn; I (II): 183-187.

Kathryn, C., Andrew, C., and Shirani, G. (2018): Fat Replacers in Baked Food Products. Foods, 7, 192; 1-12. Kia, S., and Hosseini, G. (2018): Development of traditional date cookie formulation using pumpkin puree. Journal of Food Biosciences and Technology, 8(2), 69-78.

Kocer, D., Hicsasmaz, Z., Bayindirli, A., and Katnas, S. (2007): Bubble and pore formation of the high-ratio cake formulation with polydextrose as a sugar-and fat-replacer. Journal of Food Engineering, 78(3), 953-964.

Kulkarni, A., and Joshi, D., (2013): Effect of replacement of wheat flour with pumpkin powder on textural and sensory qualities of biscuit. International Food Research Journal; 20(2): 587-591.

Latimer, G., (2012): Official Methods of Analysis of AOAC International. Gaithersburg, Md. AOAC International; ISBN: 9780-935584-83-7.

Meilgaard, M., Civille, G., and Carr, B. (2007): Sensory Evaluation Techniques. 4th ed. London: Taylor and Francis. Boca

Raton: 1-464.

Michel, C., Maria de, F., Rafaela, C., Juciane de, R. (2016): Chemical composition of unripe banana peels and pulps flours and its effects on blood glucose of rats. Nutrition \& Food Science. July. 504-516.

Nguyen, V., and Nguyen, T. (2018): Production of high-quality flour and the made biscuits from Pumpkin. International Journal of Food Science and Nutrition; Volume 3; Issue 5; September 2018; 157-166.

Noor Aziah, A., Lee Min, W., and Bhat, R. (2011): Nutritional and sensory quality evaluation of sponge cake prepared by incorporation of high dietary fiber containing mango 
(Mangiferaindica var. Chokanan) pulp and peel flours. International journal of food sciences and nutrition, 62 (6), 559567.

Omayma, E., and Youssef, M. (2007): Fat Replacers and Their Applications in Food Products: A Review. Alex. J. Fd. Sci. \& Technol; 4(1): 29-44.

Onabanjo, O., and Dickson, A. (2014): Nutritional, functional and sensory properties of biscuit produced from wheat-sweet potato composite. Journal of Food Technology Research; 1:111121.

Pieterse, Z. (2003): Avocados (monounsaturated fatty acids), weight loss and serum lipids. Energy kJ; 26:65-71.

Pooja, M., Indrani, M., and Simmi, J. (2018): Study on the physico-chemical and sensory characteristics of cookies made using avocado as a fat (Butter) substitute. International Journal of Food Science and Nutrition; 3(1); January; : 68-72.

Renehan, A., Tyson, M., Egger, M., Heller, R., and Zwahlen, M. (2008): Body-mass index and incidence of cancer: A systematic review and meta-analysis of prospective observational studies. Lancet; 371, 569-578.

Romanchik-Cerpovicz, J., Jeffords, M., and Onyenwoke, A. (2018): College student acceptance of chocolate bar biscuits containing puree of canned green peas as a fat-ingredient substitute; J. Culin. Sci. Technol; 17(6): 507-518.

Roxana, E., Mihaela, A., and Ovidiu, (2018): Muffins Obtained with Some Vegetal Powders as Fat Replacers; Bulletin UASVM Animal Science and Biotechnologie; $75(1)$ : 21-27.

Sanaa, A. (2015): Effect of Wheat Bran and Barley as Fat Replacers on Quality Characteristics Beef Sausage during Frozen Storage. Middle East J. Appl. Sci., 5(2): 618-629.

Seher, S., and Sedat, S., (2017): The effect of the replacement of fat with carbohydrate-based fat replacers on the dough properties and quality of the baked pogaca: a traditional high-fat bakery product. Food Sci. Technol, Campinas, 37(1): 25-32.

Shouk, A., and Sawsan, Y. (2005): Effect of Fat Replacers and Hull-Less Barley Flour on Low-Fat Croissant Quality. Pol. J. Food Nutr. Sci; 14/55, (3), 287-292. 
Snedecor, G., and Cochran, W. (1994): Statistical Methods. 8th Edn., East-West Press Pvt. Ltd., New Delhi, India, pp: 313.

Sneha, S., Genitha, T., and Vrijesh, Y. (2012): Preparation and quality evaluation of flour and biscuit from sweet potato. Journal of Food Processing and Technology; 3(12): 1-6.

Wang, S., Lin, T., Man, G., Li, H., Zhao, L., Wu, J., and Liao, X. (2014): Effects of anti-browning combinations of ascorbic acid, citric acid, nitrogen and carbon dioxide on the quality of banana smoothies. Food Bioprocess Technol, 7(1), 161-173.

Wekwete, B., and Navder, K. (2008): Effects of avocado fruit puree and oatrim as fat replacers on the physical, textural and sensory properties of oatmeal cookies. Journal of food quality; 31(2):131-141.

Whitlock, G., Lewington, S., Sherliker, P., Clarke R., Emberson J., Halsey J., Qizilbash N., and Arvanitoyannis, I., (2000): Low-fat/calorie foods: current state and perspectives. Critical Reviews in Food Science and Nutrition, 40(5), 427e447.

Wilton, B. (2014): Baking Alternatives- Reducing Fat in Your Favourite Baked Goods Recipes. Ideas from Wilton.

World Health Organization (W.H.O.) (2007): Prevention of Cardiovascular Disease; World Health Organization: Geneva, Switzerland.

Zahn, S., Pepke, F., and Rohm, H. (2010): Effect of inulin as a fat replacer on texture and sensory properties of muffins. International Journal of Food Science \& Technology, 45(12), 2531-2537. 
مجلة البحوث فى مجالات التربية النوعية

\section{مهيروس الفاكهة وتطبقاته كبديل للاهون في البسكويث}

إعداد

1'اريمان سعيد اسحق\& \&محد يوسف عبد الحميا محمود

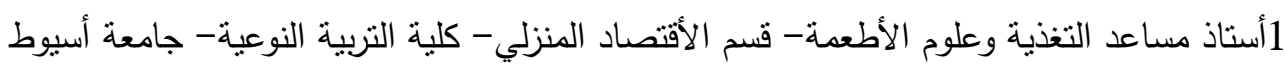

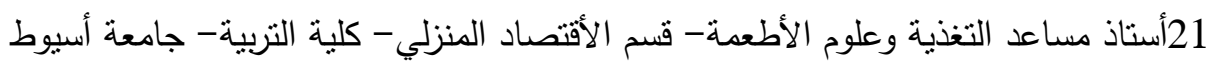

\section{الملخص العريي}

هذه الدراسة أجريت لتقييم تأثير ثلاثة أنواع من مهروس الفاكهة وهي (التفاح، الموز ، الكانتالوب) والتي أستخدمت كبديل للدهون في تصنيع البسكويت بثلاث نسب (5:25 و 50:50 و 100: صفر) ومقارنتهح بالعينة الضابطة (100\% دهون) من حيث التركيب الكيميائي، والخصائص الفيزيائية والوظيفية والتقييم الحسي للبسكويت. أظهرت النتائج عدم وجود فرق معنوي في الرطوبة بين جميع العينات مقارنة بالعينة الضابطة حيث كانت أعلي نسبة للرطوبة (2,59) في عينات أستبدال الدهون بنسبة 100\%. أيضاً زاد محتوي البسكويت من الألياف والرماد والكربوهيدرات بشكل ملحوظ كلما زاد مستوي أستبدال مهروس الفاكهة. كذلك في المقابل أدي الأستبدال إلي إنخفاض كبير في محتوي الدهون. أيضاً أظهرت النتائج زيادة معنوية عند عند القيمة الأحتمالية أقل من 0,05 بين العينات بالنسبة لوزن وسمك البسكويت ولكنه انخفض في العرض والحجم والوزن النوعي. كذلك لوحظ أن أعلي قيمة للوزن والسمك كان في عينات أستبدال الدهون بنسبة 100\% وهي كالتالي (20,0\% \& \&20,01 16,33\%) في الوصفات (4,3,2) علي الترتيب ، بينما أقل القيم كانت في عينات أستبدال الدهون بنسبة 50\% وهي كالتالي (16,0\% \& 13,67\% 12,52\%) علي الترتيب. أما بالنسبة للرقم الهيدروجيني لجميع العينات فقد كان مختلفاً بشكل كبير مقارنة بالعينة الضابطة. أيضاً لوحظ أن كفاءة أمتصاص الماء بالنسبة لعينات أستبدال الدهون بنسبة 100 أعلي من مثنلتها بنسبة 50\%. بالنسبة للمظهر والنكهة والطعم والملمس 
والقبول العام لجميع البسكويت الذي تم أستبداله بمهروس الفاكهة لويظهر أي أختلاف معنوي مقارنة بالعينة الضابطة وكان مقبولا بدرجة عالية بإستثناء المظهر والملمس في عينة أستبدال الدهون بالتفاح 100\% فقد أظهرت أختلافات معنوية عند القيمة الأحتمالية أقل من 0,05 ـ

الكلمات المفتاحية : مهروس الفاكهة، التركيب الكيميائي، الخواص الوظيفية والفيزيائية، التقييم الحسي 